\title{
Subtask 1.17 - Subcritical Water Extraction of Mercury From Soils and Sediments
}

\author{
Final Report \\ November 12, 1998 \\ By: \\ Steven B. Hawthorne
}

RECEIVE

NOV 191998

O.STI

Work Performed Under Contract No.: DE-FC21-93MC30097

For

U.S. Department of Energy

Office of Fossil Energy

Federal Energy Technology Center

P.O. Box 880

Morgantown, West Virginia 26507-0880

By

Energy \& Environmental Research Center

University of North Dakota

P. O. Box 9018

Grand Forks, North Dakota 58202-9018 


\section{Disclaimer}

This report was prepared as an account of work sponsored by an agency of the United States Government. Neither the United States Government nor any agency thereof, nor any of their employees, makes any warranty, express or implied, or assumes any legal liability or responsibility for the accuracy, completeness, or usefulness of any information, apparatus, product, or process disclosed, or represents that its use would not infringe privately owed rights. Reference herein to any specific commercial product, process, or service by trade name, trademark, manufacturer, or otherwise does not necessarily constitute or imply its endorsement, recommendation, or favoring by the United States Government or any agency thereof. The views and opinions of authors expressed herein do not necessarily state or reflect those of the United States Government or any agency thereof. 


\section{DISCLAIMER}

Portions of this document may be illegible in electronic image products. Images are produced from the best available original document. 


\section{DISCLAIMER}

This report was prepared as an account of work sponsored by an agency of the United States Government. Neither the United States Government, nor any agency thereof, nor any of their employees makes any warranty, express or implied, or assumes any legal liability or responsibility for the accuracy, completeness, or usefulness of any information, apparatus, product, or process disclosed or represents that its use would not infringe privately owned rights. Reference herein to any specific commercial product, process, or service by trade name, trademark, manufacturer, or otherwise does not necessarily constitute or imply its endorsement, recommendation, or favoring by the United States Government or any agency thereof. The views and opinions of authors expressed herein do not necessarily state or reflect those of the United States Government or any agency thereof.

Available to the public from the National Technical Information Service, U.S. Department of Commerce, 5285 Port Royal Road, Springfield, VA 22161; phone orders accepted at (703) 487-4650.

\section{ACKNOWLEDGMENT}

This report was prepared with the support of the U.S. Department of Energy (DOE) Federal Energy Technology Center; however, any opinions, findings, conclusion, or recommendations expressed herein are those of the author(s) and do not necessarily reflect the views of DOE.

\section{EERC DISCLAIMER}

LEGAL NOTICE This research report was prepared by the Energy \& Environmental Research Center (EERC), an agency of the University of the account of work sponsored by the U.S. Department of Energy. Because of the researen Nothe dork

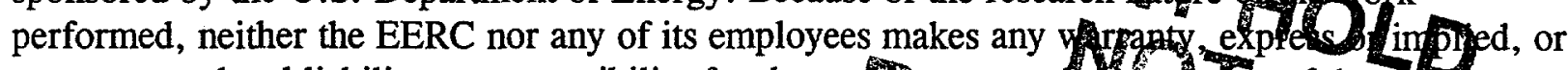
assumes any legal liability or responsibility for the accur competertess of usefulness on any information, apparatus, product, or process disclosed, of upe wo not infringe privately owned rights. Reference herein to any specific commercraf plad gofs, sc service by trade name, trademark, manufacturer, or otherwise does not necessarily constitume bisply its endorsement or recommendation by the EERC. 


\section{TABLE OF CONTENTS}

LIST OF TABLES $\ldots \ldots \ldots \ldots \ldots \ldots \ldots \ldots \ldots \ldots \ldots \ldots \ldots \ldots \ldots \ldots \ldots$

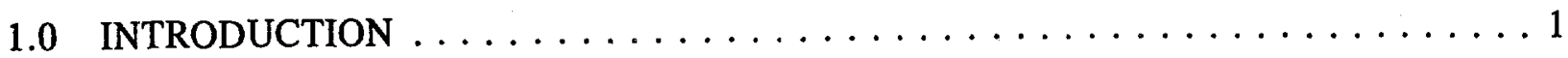

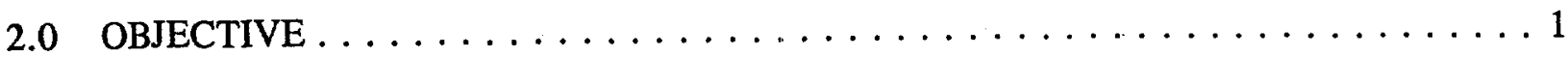

$3.0 \quad$ SPECIFIC.DELIVERABLES $\ldots \ldots \ldots \ldots \ldots \ldots \ldots \ldots \ldots \ldots \ldots \ldots \ldots \ldots \ldots$

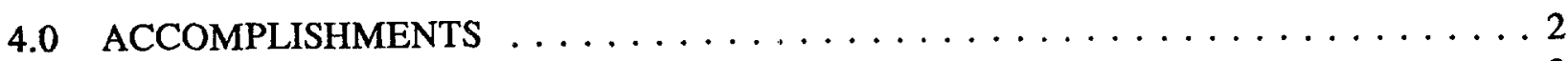

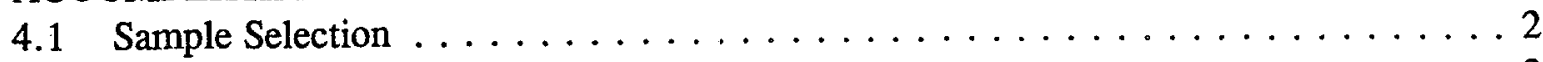

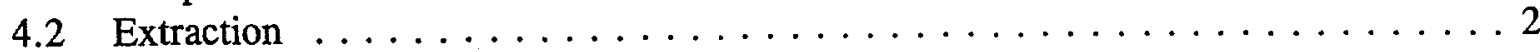

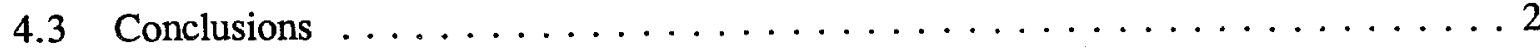

\section{LIST OF' TABLES}

1 Mercury Removal Efficiencies Using Subcritical Water $\ldots \ldots \ldots \ldots \ldots \ldots$

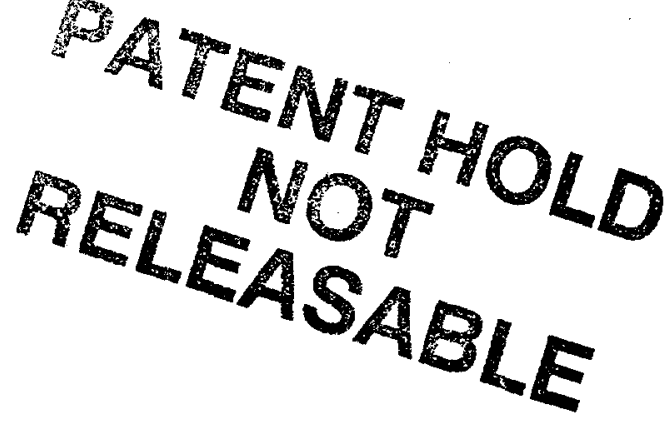




\section{SUBTASK 1.17 - SUBCRITICAL WATER EXTRACTION OF MERCURY FROM SOILS AND SEDIMENTS}

\subsection{INTRODUCTION}

The U.S. Environmental Protection Agency (EPA) "National Sediment Quality Survey" lists the top pollutants responsible for toxicity in watersheds as 1) PCBs (polychlorinated biphenyls), 2) mercury, and 3) other organics such as PAHs (polycyclic aromatic hydrocarbons) and pesticides. In addition, these same pollutants are major contributors to chemical pollution on U.S. Department of Energy (DOE) and other contaminated sites (e.g., industrial sites and harbors). An ideal remediation method would allow cost-effective removal of both organic and mercury contamination using a single process.

The Energy \& Environmental Research Center (EERC) has demonstrated that controlling the temperature (and to a lesser extent, the pressure) of water can dramatically change its ability to extract organics and inorganics from matrices ranging from soils and sediments to waste sludges and coal. The dielectric constant of water can be changed from ca. 80 (a very polar solvent) to $<5$ (similar to a nonpolar organic solvent) by controlling the temperature (from ca. ambient to ca. $400^{\circ} \mathrm{C}$ ) and pressure (from ca. 5 to 350 bar). The EERC has shown that hazardous organic pollutants such as pesticides, PAHs, and PCBs can be completely removed from soils, sludges, and sediments at temperatures $\left(250^{\circ} \mathrm{C}\right)$ and pressures $(<50 \mathrm{~atm})$ that are much milder than typically used for supercritical water processes (temperature $>374^{\circ} \mathrm{C}$, pressure $>221 \mathrm{~atm}$ ). In addition, the process has been demonstrated to be particularlyetefective for samples containing very high levels of contaminants (e.g., parts per thousand).

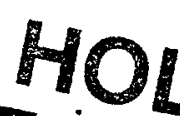

The EERC has also demonstrated that mercury can betrater at much harsher conditions $\left(400^{\circ} \mathrm{C}\right.$ and $>300$ atth $)$ entoval of mercury from contaminated solids at the lower temperature and pressu $19.9250^{\circ} \mathrm{C}$ and $50 \mathrm{~atm}$ ) has not been investigated. If successful, this project will provide the basis extract both organic contaminants and mercury from contaminated solids in a single-step process.

\subsection{OBJECTIVE}

- To determine the ability of hot/liquid water to extract mercury from contaminated soils and/or sediments using the same conditions of temperature and pressure that have previously been successful for removing organic pollutants including PAHs, PCBs, and pesticides.

\subsection{SPECIFIC DELIVERABLES}

- The ability (and conditions) of hot/liquid water to remove mercury from three or more highly contaminated soils and/or sediments will be reported. 


\subsection{ACCOMPLISHMENTS}

\subsection{Sample Selection}

Three samples were selected for extraction. All samples are "real-world"; e.g., they were collected from contaminated environmental sites and used without significant preparation. One of the samples was obtained from the National Institute of Standards and Testing (NIST), so that certified values of the mercury concentrations were available. The three samples were contaminated (total mercury values) at 50,213, and $3380 \mathrm{ppm}$.

\subsection{Extraction}

Extractions have been performed using a subcritical water extraction apparatus developed for this project. Flow rates were ca. $1 \mathrm{~mL} /$ minute. Sufficient pressure was maintained during the extractions to keep the water in the liquid state (ca. 50 bar and 100 bar for $250^{\circ}$ and $300^{\circ} \mathrm{C}$, respectively). Problems were encountered with plugging of the 1/16-in.-OD outlet lines for the most highly contaminated samples. Since the extraction cell outlet contained a $0.5-\mu \mathrm{m}$ frit, the plugging appeared to be deposition of extracted material as the extractant water was cooled. Successful extractions of the most highly contaminated sample were performed by using 2-g samples in a 3.4-mL extraction cell and placing an empty $0.8-\mathrm{mL}$ cell after the sample cell before the water was cooled.

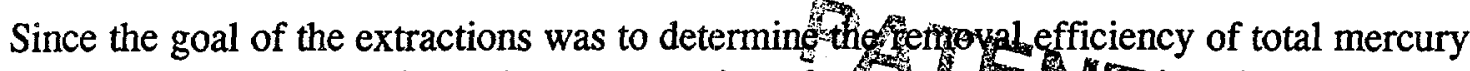
using subcritical water extractions, the concentration of mercting soils and in the soil residues after extraction. The results of the extractions are sin m zepr Table 1. As shown, the conditions typically used for the removal of fanc pollutants $\mathrm{n}$.m soils show substantial removal of mercury from the test sois in to to prinutes at conditions previously used to remove organic pollutants such as PAHs, PCBs, and pestad ( $153^{\circ}$. Increasing the temperature to $300^{\circ} \mathrm{C}$ also increases the rate of extraction (Table 1). For thes with lower contamination levels, 30 minutes at $250^{\circ} \mathrm{C}$ was sufficient to remove ca. $95 \%$ of the mercury. However, extraction for 30 minutes at $250^{\circ} \mathrm{C}$ for the sample with $3380 \mathrm{ppm}$ of mercury contamination was sufficient for only $45 \%$ removal. Additional extraction time (60 minutes) at $250^{\circ} \mathrm{C}$ resulted in $67 \%$ removal (Table 1 ), indicating that the removal of mercury was limited by its solubility in the subcritical water. However, when the extraction temperature was raised to $300^{\circ} \mathrm{C}$, 30 minutes of extraction was sufficient to remove $84 \%$ of the mercury from this highly contaminated sample.

\subsection{Conclusions}

Subcritical water extraction can be used to remove mercury from highly contaminated soils. The conditions required $\left(250^{\circ}\right.$ to $\left.300^{\circ} \mathrm{C}\right)$ have previously been shown to yield quantitative removal of common organic pollutants such as PCBs and PAHs (e.g., coal tar), demonstrating that subcritical water extraction may be a useful approach for the remediation of materials cocontaminated with mercury and organic pollutants. 
TABLE 1

Mercury Removal Efficiencies Using Subcritical Water

\begin{tabular}{lccc}
\hline & Soil A & Soil B & Soil C (NIST) \\
\hline Initial Concentration, ppm & 213 & 3380 & 50 (43)* \\
Concentration after $250^{\circ} \mathrm{C}, 15 \mathrm{~min}, \mathrm{ppm}$ & 61 & 2190 & 6.2 \\
$\mathrm{Hg}$ Removed after $250^{\circ} \mathrm{C}, 15 \mathrm{~min}, \%$ & 71 & 35 & 87 \\
Concentration after $250^{\circ} \mathrm{C}, 30 \mathrm{~min}, \mathrm{ppm}$ & 10.5 & 1860 & 2.8 \\
Hg Removal after $250^{\circ} \mathrm{C}, 30 \mathrm{~min}, \%$ & 95 & 45 & 94 \\
Concentration after $250^{\circ} \mathrm{C}, 60 \mathrm{~min}, \mathrm{ppm}$ & - & 1110 & - \\
Concentration after $250^{\circ} \mathrm{C}, 60 \mathrm{~min}, \%$ & - & 67 & - \\
Concentration after $300^{\circ} \mathrm{C}, 30 \mathrm{~min}, \mathrm{ppm}$ & 1.1 & 551 & 3.4 \\
Hg Removal after $300^{\circ} \mathrm{C}, 30 \mathrm{~min}, \%$ & 99 & 84 & 93 \\
\hline
\end{tabular}

*The concentration certified by NIST was $50 \mathrm{ppm} ; 43 \mathrm{ppm}$ was determined by the EERC.

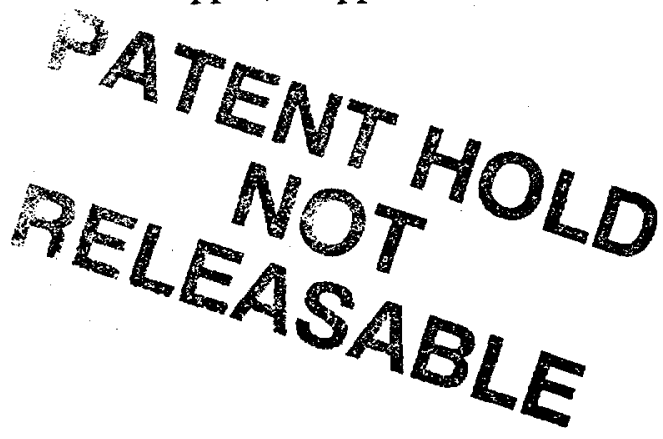

